\title{
The beneficial role of vitamin $D$ in obesity: possible genetic and cell signaling mechanisms
}

\author{
Khanh vinh quốc Lương* and Lan Thi Hoàng Nguyễn
}

\begin{abstract}
The prevalence rates of overweight and obesity are considered an important public issue in the United States, and both of these conditions are increasing among both children and adults. There is evidence of aberrations in the vitamin D-endocrine system in obese subjects. Vitamin D deficiency is highly prevalent in patients with obesity, and many studies have demonstrated the significant effect of calcitriol on adipocytes. Genetic studies have provided an opportunity to determine which proteins link vitamin D to obesity pathology, including the vitamin $D$ receptor, toll-like receptors, the renin-angiotensin system, apolipoprotein $\mathrm{E}$, vascular endothelial growth factor, and poly (ADP-ribose) polymerase-1. Vitamin D also exerts its effect on obesity through cell-signaling mechanisms, including matrix metalloproteinases, mitogen-activated protein kinase pathways, the reduced form of nicotinamide adenine dinucleotide phosphate, prostaglandins, reactive oxygen species, and nitric oxide synthase.

In conclusion, vitamin D may have a role in obesity. The best form of vitamin D for use in the obese individuals is calcitriol because it is the active form of the vitamin $D_{3}$ metabolite, its receptors are present in adipocytes, and modulates inflammatory cytokine expression.
\end{abstract}

\section{Background}

Obesity is an emerging health problem of growing importance. There is evidence of aberrations in the vitamin D-endocrine system in obese subjects [1], such as increases in serum parathyroid hormone (PTH), urinary cyclic adenosine $3,5^{\prime}$-monophosphate (cAMP), renal tubular reabsorption of calcium, and circulating $1 \alpha, 25-$ hydroxyvitamin $\mathrm{D}_{3}\left(1,25 \mathrm{OHD}_{3}\right)$ and a decrease in serum 25-hydroxyvitamin $\mathrm{D}_{3}$ (25OHD) levels. In young adults, the dietary plus supplemental vitamin $\mathrm{D}$ intake was inversely related to the development of incident metabolic syndrome over 20 years of follow-up [2]. Vitamin $\mathrm{D}$ deficiency is common in children in West Virginia and is associated with increasing age and obesity [3]. Vitamin D deficiency is an independent risk factor for obesity and abdominal obesity in women [4]. Obese women transfer less 25OHD to offspring than normalweight women, despite similar serum levels; maternal obesity and vitamin D sufficiency are associated with cord-blood vitamin D insufficiency [5]. Visceral adipose tissue is negatively associated with plasma 25OHD

\footnotetext{
* Correspondence: Lng2687765@aol.com

Vietnamese American Medical Research Foundation, 14971 Brookhurst Street, Westminster, CA 92683, USA
}

concentrations in South Asians [6]. Total body fat has been shown to be a negative predictor of 25OHD levels in women even after controlling for age, lifestyle, and PTH in Germany [7]. Vitamin D deficiency has been associated with obesity, visceral obesity, hypertriglyceridemia, and metabolic syndrome in Korean children [8]. Body mass index (BMI) is inversely associated with the increase in the serum 25OHD levels in response to vitamin D supplementation [9]. The expression of vitamin D-metabolizing enzymes has been demonstrated in human adipose tissue. Plasma 25OHD increased by $27 \%$ after weight loss in the obese individuals. The expression levels of the 25-hydroxylase CYP2J2 and the $1 \alpha-$ hydroxylase CYP27B1 were decreased by $71 \%$ and $49 \%$, respectively, in the subcutaneous adipose tissue of obese subjects [10], suggesting that adipose tissue, which can be dynamically altered during obesity and weight loss, has the capacity to metabolize vitamin D locally. Furthermore, calcitriol directly regulates adipocyte $11 \beta$-hydroxysteroid dehydrogenase type 1 (11ß-HSD-1), generating active cortisol from inactive cortisone, with expression and cortisol production in human adipocytes in vitro [11], suggesting a potential role for calcitriol in visceral adiposity. In a 12-week double-blind randomized clinical trial, cholecalciferol supplementation resulted in a statistically significant decrease 
in body fat mass in healthy and obese women compared with the placebo group [12]. In addition, vitamin $\mathrm{D}_{3}$ supplementation also improved insulin sensitivity in apparently healthy, middle-aged, centrally obese men [13]. In our previous publication, we discussed the role of vitamin $\mathrm{D}$ in obesity [14]. These findings suggest that vitamin D may play a role in obesity. Herein, we further discuss the potential role of vitamin D in obesity, along with possible genetic and cell signaling mechanisms.

\section{Genetic factors that relate to vitamin D and obesity}

Genetic studies provide an opportunity to link molecular variations with epidemiological data. DNA sequence variations, such as polymorphisms, exert both modest and subtle biological effects. Vitamin D exhibits immunemodulatory and anti-proliferative effects through the vitamin $\mathrm{D}$ receptor (VDR) in disease states. The VDR is present in adipose tissue and may contribute to the action of vitamin $\mathrm{D}$ and its analogs in adipocytes. Specific calcitriol-binding is evident in pre-adipocyte 3T3-L1 cells, but there is no evidence of specific calcitriol-binding in mature adipocytes [15]. This finding is consistent with the idea that any influence of vitamin $\mathrm{D}$ on adipogenesis would likely be exerted early in the pre-adipocyte to adipocyte transition when more VDR was available. However, Blumberg et al. [16] have further defined the molecular mechanism by which unliganded VDR and calcitriolliganded VDR regulate adipogenesis. They also demonstrated that VDR is expressed early in adipogenesis. VDR were expressed sequentially at high, but short-lived, levels beginning at $30 \mathrm{~min}$ and lasting for only a few hours after adipogenic activation $[17,18]$. A functional vitamin D response element was identified in the murine Insig-2 promoter, and its potential role is involved in the differentiation of 3T3-L1 preadipocytes [19]. VDR-knockout mice have also displayed atrophy of adipose tissue surrounding the prostate and mammary glands $[20,21]$. Under normocalcemic conditions, VDR-null mice displayed less body fat mass and lower plasma triglyceride and cholesterol levels compared with wild-type (WT) mice. When placed on a high-fat diet, VDR-null mice displayed a slower growth rate and accumulated less fat mass globally than WT mice, even when their food intake and intestinal lipid transport capacity were the same as WT mice [22-24]. In one study, transgenic mice with targeted expression of human VDR in the adipose tissue developed obesity due to reduced energy expenditure [25]. Taken together, these data confirm an important role of the VDR in the control of adipocyte metabolism and the regulation of energy metabolism. Variations at the VDR locus have been associated with susceptibility and progression to several diseases. $V D R$ gene polymorphisms have been linked to higher susceptibility to vitamin $D$ deficiency in children and adolescents [26]. The VDR TaqI allele is associated with obesity [27,28]; BsmI and ApaI VDR genes are also significantly associated with overweight and obesity [29], and the BsmI $V D R$ polymorphism appeared to influence body mass index [30]. These observations suggested that alterations of $V D R$ function may play a role in patients with obesity.

Toll-like receptors (TLRs) are a group of glycoproteins that function as surface trans-membrane receptors. These receptors are involved in the innate immune response to exogenous pathogenic microorganisms. Substantial evidence exists supporting the important role of TLRs in the pathogenesis of obesity. Both TLR-2 and TLR-4 expression are increased in adipose tissue in patients with obesity and type 2 diabetes mellitus [31]. A high-fat dietor leptin deficiency-induced obesity up-regulated the expression of TLR1-9 and TLR11-13 in murine adipose tissue. The extent of the obesity-induced up-regulation of most TLR genes and related pro-inflammatory signaling cascades was much greater in the epididymal adipose tissues than in the subcutaneous fat tissues of the mice with diet-induced obesity [32]. These results suggest that TLRs and the related pro-inflammatory signaling molecules that are overexpressed in enlarged adipose tissues may play an important role in the obesity-associated phenomenon of meta-inflammation. In addition, adipose stores may play a dynamic role in the regulation of inflammation and innate immunity in human subjects via modulation of the TLR/ Nuclear Factor-kappaB (NF-kB) regulatory pathway [33]. TLR-4-deficient $10 \mathrm{ScN}$ mice were selectively protected against obesity-induced by diets high in saturated fat. Moreover, macrophage infiltration and monocyte chemotactic protein-1 (MCP-1) transcript abundance were lower in the adipose tissue of $10 \mathrm{ScN}$ mice fed an HFP diet [34]. $\mathrm{C} 3 \mathrm{H} / \mathrm{HeJ}$ mice, which have a loss-of-function mutation in $T L R-4$, were protected against the development of dietinduced obesity [35] and were less susceptible to fatinduced inflammation and insulin resistance [36]. The inhibition of TLR-2 expression improved insulin sensitivity and signaling in the muscle and white adipose tissue of mice fed a high-fat diet [37]. These findings suggest that TLRs are a key modulator of the crosstalk between the inflammatory and metabolic pathways. Furthermore, there is an association between TLR-2 and TLR-4 polymorphisms and serum levels of tumor necrosis factor-alpha and its soluble receptors in obese children [38], suggesting that serum cytokine levels may be affected by TLR polymorphisms in obese children. In contrast, vitamin D deficiency increases the expression of the hepatic mRNA levels of TLR-2, TLR-4, and TLR-9 in obese rats [39]. However, calcitriol suppresses the expression of TLR-2 and TLR-4 mRNA and protein in human monocytes and triggers hypo-responsiveness to pathogen-associated molecular patterns [40]. Calcitriol has also been shown to down-regulate intracellular TLR-2, TLR-4 and TLR-9 
expression in human monocytes [41]. Interestingly, TLR activation up-regulates the expression of VDR and $1 \alpha-$ vitamin D hydroxylase in human monocytes [42]. Taken together, these data indicate that vitamin D may have a role in obesity via modulating the TLR pathways.

The primary function of the renin-angiotensin system (RAS) is to maintain fluid homeostasis and to regulate blood pressure. Angiotensin-converting enzyme (ACE) is a key enzyme in the RAS and converts angiotensin (AT) I to the potent vasoconstrictor AT II [43]. A local RAS has been described in adipose tissue. Human adipose tissue expresses angiotensinogen and RAS enzymes [44]. Angiotensinogen, ACE and type 1 AT receptor genes are widely expressed, both in human adipose tissue and in cultured human adipocytes [45]. Renin is synthesized and secreted by culture 3T3-L1 cells in a regulated manner [46]. The renin receptor protein is specifically synthesized in the stromal portion of human adipose tissue in both isolated inter-adipocyte stromal cells and in stromal areas [47]. Moderate weight loss reduces plasma renin and aldosterone levels [48], suggesting an effect of weight loss on the juxta-glomerular secretion of renin. The RAS has been implicated in a variety of adipose tissue function. AT II increases lipogenesis in cultured human and murine cells [49], and angiotensinogenknockout mice display decreased weight gain and decreased adipocyte cell size [50]. The deletion of the $\mathrm{AT}_{2}$ receptor reduces adipose cell size and protects from diet-induced obesity and insulin resistance [51]. $\mathrm{AT}_{2}$ receptor deficiency attenuates adipocyte differentiation and decreases adipocyte number in atherosclerotic mice [52]. These results suggest that $\mathrm{AT}_{2}$ receptor stimulation in adipose tissue is involved in the improvement of adipocyte differentiation and adipose tissue dysfunction in atherosclerotic models. Local renin angiotensin expression regulates human mesenchymal stem cell differentiation to adipocytes. Combined treatment with exogenous AT II and the AT II type 1 receptor blocker valsartan further inhibited adipogenesis [53]. Obese Zucker rats exhibited a marked up-regulation of $\mathrm{AT}_{1}$ receptor mRNA expression [54]. ACE inhibition and $\mathrm{AT}_{1}$ receptor blockade prevented fatty liver and fibrosis in obese Zucker rats [55]. These findings suggest that the RAS plays a role in obesity. The RAS activity may be modified by variants of the genes coding functional proteins of this pathway. Among hypertensive subjects with metabolic syndrome, the presence of $A C E$ polymorphisms, including TT235, MM174, DD, and CC1166 genotypes, could be a risk factor for central obesity and dyslipidemia [56]. In response to low-energy diets in obese women, the reduction in body fat was significantly lower in patients with the $A C E D / D$ genotype than the $I /$ $I$ plus $I / D$ genotype [57]. There is an association of $A C E$ gene polymorphisms with BMI in the hypertensive
Tunisian population [58]. In the Olivetti Prospective Heart Study, the $A C E I / D$ polymorphism was a significant predictor of overweight and abdominal adiposity in men, while $D D$ homozygosity was associated with larger increases in body weight and blood pressure in aging persons, and with higher overweight incidence [59]. There was a significant association of the $I / D$ polymorphism with obesity, but only in Caucasian men [60]. It is possible that hormonal differences between sexes may alter the influence that the $A C E I / D$ polymorphism has on weight gain. However, there is also an interaction between vitamin D and the RAS. Lower 25OHD levels and higher BMI values have been associated with higher plasma renin and aldosterone concentrations in Indian subjects with hypertension [61]. Vitamin D metabolites have been inversely associated with circulating renin [62]. Genetic disruption of the VDR results in overstimulation of the RAS with increasing renin and angiotensin II productions, leading to high blood pressure and cardiac hypertrophy. Treatment with captopril reduced cardiac hypertrophy in VDR-knockout mice [63]. The inactivation of $1 \alpha$-hydroxylase, inhibiting calcitriol production, also leads to the development of hypertension, cardiac hypertrophy and impaired cardiac function, along with an up-regulation of the RAS in both renal and cardiac tissues, which could be reduced with calcitriol treatment [64]. In contrast, VDR over-expression suppresses renin expression in the juxtaglomerular cells of mice independently of PTH and calcium [65]. These findings suggest that calcitriol may function as an endocrine suppressor of renin biosynthesis. Calcitriol suppresses renin gene transcription by blocking the activity of the cyclic AMP response element in the renin core promoter [66] and decreases ACE activity in bovine endothelial cells [67]. There was a positive association identified between 25OHD and the vascular sensitivity to AT II in obese Caucasians with hypertension [68]. Vitamin $\mathrm{D}_{3}$ therapy in obese subjects with hypertension modified renal plasma flow, mean arterial pressure, and tissue sensitivity to AT II similar to ACE inhibition [69]. Taken together, these findings indicate that the RAS is activated in obese patients and that vitamin D may play a role in patients with obesity by modulating the RAS.

Apolipoprotein $\mathrm{E}$ (apoE) is a plasma protein and a key regulator of cholesterol and lipid metabolism. ApoE mRNA and protein can be found in human and rodent adipose tissue [70,71]. The infusion of AT II into mice for 3 days significantly reduced apoE expression in adipocytes from freshly isolated adipose tissue. In isolated human adipocytes, treatment with AT II significantly reduced cellular and secreted apoE (by 20-60\%). However, a specific $\mathrm{AT}_{1}$ receptor blocker, valsartan, eliminated the effect of AT II on adipocyte apoE expression [72]. In in vivo and in vitro experiments, endogenous 
adipocyte apoE expression modulated adipocyte lipid metabolism and adipocyte gene expression [71]. Endogenous adipocyte apoE expression has important implications for the acquisition of substrate from triglyceride-rich lipoprotein particles such as very-low-density-lipoprotein (VLDL) [73]. High expression of apoE impairs lipid storage and promotes cell proliferation in human adipocytes [74]. ApoE-knockout adipocytes are lipid-poor and triglyceride synthesis is lower compared to wild-type adipocytes in the absence and presence of extracellular VLDL. Macrophage-derived apoE ameliorates dyslipidemia and atherosclerosis in lean and obese apoE-deficient mice $[75,76]$, suggesting that apoE plays a role in regulating dyslipidemia. In comparison with ApoE3 mice, ApoE2 mice had elevated fasting plasma lipid and insulin levels and displayed prolonged postprandial hyperlipidemia accompanied by increased granulocyte number and inflammation 2 hours after being fed a lipid-rich meal. In comparison with ApoE3 mice, the ApoE2 mice also presented increased adiposity when maintained on a Western-type, high-fat, high-cholesterol diet [77]. ApoE2-expressing mice were hyperlipidemic and had increased gonadal fat pad and adipocyte sizes compared with apoE3 mice. In isolated cells, however, the expression of the apoE2 isoform produced defective lipogenesis and increased triglyceride hydrolysis [78]. The ApoE4 allele is associated with higher serum vitamin D levels [79]. The ApoE4 allele is associated with a low bone mass in postmenopausal Japanese women [80]. The common $A p o E$ polymorphism has a complex effect on bone metabolism in peri-menopausal Danish women during five years follow-up. Namely, among women not receiving hormone replacement therapy (HRT), those with ApoE2 have a lower rate of bone mineral loss in the femoral neck and hip regions than other women, whilst among women receiving HRT, those with ApoE4 gained more bone mineral than other women [81]. Calcitriol has been known to induce macrophages to exhibit specific saturable receptors for LDL and acetylLDL. The LDL receptor of calcitriol-induced macrophages has been found to exhibit specificity for apoB- and Econtaining lipoproteins [82]. In apoE-knockout mice, an animal model with dyslipidemia, high oxidative stress, and pronounced atherosclerosis after uninephrectomy, the animals developed reduced plaque growth and calcification with vitamin D analog treatment (paricalcitol) compared with control groups $[83,84]$. Although vitamin D deficiency is associated with an unfavorable lipid profile in cross-sectional analyses; however, Ponda et al. [85] suggest that correcting for a deficiency might not translate into clinically meaningful changes in lipid concentrations. In addition, a systematic literature search revealed no statistically significant effects for vitamin D supplementation were observed for total cholesterol, HDL and triglycerides
[86]. Therefore, the lipid modulating effects of vitamin D supplementation should be further investigated. Taken together, these findings suggest that vitamin $\mathrm{D}$ may improve lipid profiles in $A p o E$ allele obese patients.

Vascular endothelial growth factor (VEGF) is abundantly secreted from adipocytes and plays a key role in the process of fat tissue formation through the regulation of angiogenesis. A positive correlation between the concentrations of circulating VEGF levels and BMI was demonstrated in healthy male subjects under highly controlled conditions [87]. Angiogenesis has been associated with visceral and subcutaneous adipose tissue in severe human obesity [88]. The treatment of mice with TNP470, an angiogenesis inhibitor, reduced blood flow from the recipient into the graft after subcutaneous transplantation of epididymal fat. The weight of transplanted tissues and the size of adipocytes in the grafts were significantly lower in mice treated with TNP-470 (TNP mice) than in the control mice [89]. Different angiogenesis inhibitors have been shown to significantly decrease body and adipose tissue weights [90]. These studies demonstrate that adipose tissue mass can be regulated through the vasculature and that metabolic changes accompany anti-angiogenic-induced weight loss, which may contribute to weight reduction. VEGF expression in visceral fat is enhanced during growth and is related to fat deposition [91]. Serum VEGF concentrations have been positively correlated with BMI and visceral fat area [92]. In one experiment, a high fat-intake increased the VEGF mRNA expression in visceral fat and the VEGF concentration in plasma, accompanied with the increase in the plasma free fatty acids concentration in mice [93]. VEGF-B specifically controlled the endothelial uptake of fatty acids via transcriptional regulation of vascular fatty acid transport proteins [94]. Angiogenesis was inhibited by blocking the VEGF receptor 2 in mice with dietinduced obesity. These treated mice had significantly lower body weights than control animals [95]. The serum VEGF-A levels were significantly higher in obese patients than in lean controls, decreasing after weight loss with bariatric surgery [96]. VEGF haplotypes confer susceptibility to obesity in children and adolescents [97]. In contrast, calcitriol has been reported to inhibit angiogenesis in vitro and in vivo [98]. Calcitriol significantly inhibits VEGF-induced endothelial cell spouting and elongation in a dose-dependent manner and decreases the production of VEGF [99]. Calcitriol is a potent inhibitor of retinal neovascularization in a mouse model of oxygen-induced ischemic retinopathy [100]. Vitamin D and its analogs also reduce the expression of VEGF in various cancer cell lines [101,102]. Moreover, DBP-maf have been reported to inhibit angiogenesis and tumor growth in mice [103] and to inhibit VEGF signaling by decreasing VEGF-mediated phosphorylation of VEGF-2 and 
ERK1/2, a downstream target of the VEGF signaling cascade [104]. These findings suggest that vitamin D modulates angiogenesis in obesity.

Poly(ADP-ribose) polymerases (PARPs) comprise a family of enzymes sharing a conserved catalytic domain that support mono- or poly(ADP-ribosyl)transferase activity using $\mathrm{NAD}^{+}$as a donor of ADP-ribosyl units. PARPs are involved in a wide range of molecular and cellular processes, including maintenance of genome stability, regulation of chromatin structure and transcription, cell proliferation, and apoptosis [105]. PARP-1 is a critical regulator of peroxisome proliferator-activated receptor gamma (PPAR $\gamma 2)$-dependent gene expression with implications in adipocyte function and obesity-related disease models. PARP-1 expression increases during adipocyte development [106]. PARP-1 ${ }^{-/-}$mice with predominantly obesity-resistant backgrounds were more susceptible to age-related weight gain and diet-induced obesity than wild-type littermates $[107,108]$, while the decreased activity of PARP-1 in mice with obesity-prone background protected against high-fat diet-induced obesity [109-111]. These findings suggest that genetic determinants can modify the phenotypic outcomes of weight gain. PARP- $2^{-/-}$mice had defects in adipogenesis with reduced expression of adipogenic genes [112] and are also protected against diet-induced obesity [113]. PARP-5 knockout mice also exhibited increased energy expenditure, increased fatty acid and glucose utilization, and reduced adiposity [114]. In addition, increased levels of vitamin D seem to down-regulate PARP-1 expression; PARP-1 levels decrease following calcitriol treatment in NB4 cells, which are acute promyelocytic leukemia cells [115]. Vitamin D exerts a concentrationdependent inhibitory effect on PARP-1 in human keratinocyte cells [116]. Vitamin D-induced down-regulation of PARP is further enhanced by nicotinamide in human myeloblastic leukemia cells [117]. Furthermore, PARP was attenuated in the hippocampi of rats that received dexamethasone and vitamin D [118], suggesting that the antiinflammatory effects of dexamethasone and vitamin D are derived from their capacity to down-regulate microglial activation. These findings suggest that vitamin D may have a protective role in obesity by down-regulating PARP.

\section{The role of vitamin $\mathrm{D}$ in obesity}

Matrix metalloproteinases (MMPs) are proteolytic enzymes that are responsible for remodeling the extracellular matrix and regulating leukocyte migration through the extracellular matrix. This migration is an important step in inflammatory and infectious pathophysiology. MMPs are produced by many cell types, including lymphocytes, granulocytes, astrocytes, and activated macrophages. There is growing evidence that MMPs play an important role in the pathogenesis of obesity. Bouloumié et al. [119] provided the first evidence that human adipose tissue releases MMP-2. Overweight/obese women had significantly higher plasma activity of MMP2 than controls [120]. MMP-9 levels are found increased in obese subjects $[121,122]$. Significantly higher levels of MMP-9 have been reported in obese children with coexisting hypertension than in obese normotensive patients, and MMP-9 correlates with BMI [123]. In one study, obese children and adolescents had higher circulating MMP-8 concentrations, lower plasma tissue inhibitor of metalloproteinase 1 (TIMP-1) concentrations, and higher MMP-8/TIMP-1 ratios than non-obese controls [124]. An $M M P-2$ promoter haplotype was associated with percentage of body fat in childhood obesity in New Zealand [125]. Functional MMP-9 gene polymorphism is strongly associated with obesity [126], and MMP-9 genotypes and haplotypes affect MMP-9 levels in obese children and adolescents [127]. Moreover, VDR-knock-out mice have been shown to have an influx of inflammatory cells, phospho-acetylation of NF- $\mathrm{KB}$, and up-regulated expression of MMP-2, MMP-9, and MMP-12 in the lungs [128]. The VDR TaqI polymorphism is associated with the decreased production of TIMP-1, a natural MMP-9 inhibitor [129]. In addition, calcitriol modulated tissue MMP expression under experimental conditions [130], down-regulated MMP-9 levels in keratinocytes, and may attenuate the deleterious effects of excessive TNF- $\alpha$-induced proteolytic activity, which is associated with cutaneous inflammation [131]. Calcitriol also inhibits both the basal levels and the staphylococcus-stimulated production of MMP-9 in human blood monocytes and alveolar macrophages [132]. Moreover, a vitamin D analog has also been reported to reduce the expression of MMP-2, MMP-9, VEGF, and PTH-related peptide in Lewis lung carcinoma cells [111]. Together, these studies suggest that calcitriol may play an important role in the pathological processes of obesity by down-regulating the level of MMPs and regulating the level of TIMPs.

The mitogen-activated protein kinase (MAPK) pathways provide a key link between the membrane-bound receptors that receive these cues and changes in gene expression patterns, including the extracellular signal-regulated kinase (ERK) cascade, the stress-activated protein kinases/ c-jun N-terminal kinase (SAPK/JNK) cascade, and the p38 MAPK/RK/HOG cascade [133]. p38MAP kinase activity is required for human primary adipocyte differentiation [134]. Obese Zucker rats exhibit MAKP activity [54]. MAPK phosphatase-1 (MKP-1) plays an essential physiological role in the negative regulation of the MAPKs, and MKP-1 plays an important role in the regulation of energy expenditure and facilitates the loss of oxidative myofibers associated with obesity in mice [135]. Mice lacking MKP1 expression are resistant to diet-induced obesity [136]. 
The down-regulation of MKP-1 is critical for increased production of MCP-1 during the course of adipocyte hypertrophy [137]. The exposure of obese mice to UV-B resulted in the phosphorylation of ERK1/2, JNK, and p38 proteins of the MAPK family. Compared to wild-type mice, obese mice exhibited higher levels of phosphorylation of these proteins, greater activation of NF-kB/p65, and higher levels of circulating proinflammatory cytokines [138], suggesting that obesity in mice is associated with greater susceptibility to UVB-induced oxidative stress. In both dietary and genetically $(o b / o b)$ obese mice, adipose tissues displayed a marked decrease in p38MAPK activity compared with the same tissues from lean mice. Furthermore, p38MAPK activity is significantly higher in preadipocytes than in adipocytes [139], suggesting that p38MAPK activity decreases during adipocyte differentiation. The $M A P 2 K 5$-linked single nucleotide polymorphism rs2241423 was associated with BMI and obesity in two cohorts of Swedish and Greek children [140], suggesting a role for MAP2K5 in early weight regulation. By regulating VDR mRNA expression, the p38 MAPK pathway participates in the mediation of calcium signals and affects lipid accumulation in murine pre-adipocytes [141]. Pretreatment with calcitriol has been shown to inhibit JNK activation by all stressors and also to inhibit p38 activation in keratocytes [142]. Zhang et al. [143] demonstrated that the up-regulation of MKP-1 by vitamin D inhibited lipopolysaccharide (LPS)-induced p38 activation and cytokine production in monocytes and macrophages. In another study, the vitamin D analog (24R)-1,24dihydroxycholecalciferol prevented neuronal damage caused by hydrogen peroxide-induced toxicity in the $\mathrm{SH}$ SY5Y cell line [144]. Interestingly, the neurotoxic effects of hydrogen peroxide were dependent on JNK and p38 MAPK. In addition, the long-term actions of vitamin D in MCF-7 and LNCaP cancer cells can suppress the estradiol-induced activity of ERK-1 MAPK and inhibit cell growth [145].

The reduced form of the nicotinamide adenine dinucleotide phosphate (NADPH) oxidase (NOX) enzyme complex mediates critical physiological and pathological processes, including cell signaling, inflammation, and mitogenesis, by generating reactive oxygen species (ROS) from molecular oxygen. The up-regulations of $\mathrm{p} 22^{\text {phox }}$ and $\mathrm{p} 47^{\text {phox }}$ in adipose and Nox4, p $22^{\text {phox }}$, and $\mathrm{p} 47^{\mathrm{phox}}$ in the kidneys has been observed in obese subjects [146]. Overweight and obese adults have increased vascular endothelial expression levels of NOX-p47 $7^{\text {phox }}$ and evidence of endothelial oxidative stress, with selective compensatory upregulation of antioxidant enzymes and Ser1177-phosphorylated endothelial nitric oxide synthase [147]. The reduced expression of the NADPH oxidase NOX4 is a hallmark of adipocyte differentiation [148]. NOX4 acts as a switch between differentiation and proliferation in pre-adipocytes [149]. NOX4-deficient mice display latent adipose tissue accumulation and are susceptible to diet-induced obesity and early onset insulin resistance [150]. The knockdown of NOX4 by RNA interference inhibits reactive oxygen species production and adipocyte differentiation by differentiation-inducing agents [151]. The suppression of NOX2 may restore free fatty acids-induced dysfunction and apoptosis in $\beta$ cells [152]. However, vitamin D deprivation in rats decreased the activity of cytosolic NADPH-dependent 3,5,3' -triodoL-thyronine $\left(\mathrm{T}_{3}\right)$ binding in the liver. This decrease can be restored by administering calcitriol [153]. In heart mitochondria, $\mathrm{NAD}^{+}$-dependent isocitrate dehydrogenase decreased notably in vitamin D-deficient rats, but calcitriol subsequently restored normal values [154]. In rat centrilobular hepatocytes, a vitamin D-deficient diet induced a significant increase in NADPH [155]. Husain et al. [156] reported that cardiac NOX activity increased by $300 \%$ in uremic rats compared with the normal controls. Treatment with paricalcitol protected the uremic rats from cardiac oxidative stress by inhibiting NOX activity (by $50 \%$ ), thus lowering superoxide production in the heart. Taken together, these findings and results indicate that vitamin D may have a role in obesity via the suppression of NADPH expression.

Prostaglandins (PGs) play a role in inflammatory processes. Cyclooxygenase (COX) participates in the conversion of arachidonic acid into PGs. $\mathrm{PGE}_{2}$ and $\mathrm{PGD}_{2} / \mathrm{PGJ}_{2}$ have shown to promote adiposity in mice through the inhibition of lipolysis and the induction of adipogenesis, respectively $[157,158]$. $\mathrm{PGF}_{2 \alpha}$ is a potent inhibitor of adipocyte differentiation in vitro [159-161]. $\mathrm{PGE}_{2}$ enhanced lipid accumulation in hepatocytes and contributed to the development of hepatic steatosis in in vivo models of obesity [162]. Obesity-associated inflammatory foci in the human breast are associated with elevated COX-2 levels and activation of the $\mathrm{PGE}_{2}$ [163]. In one study, a COX-2 genetic deficiency produced in a significant reduction in total body weight and percentage of body fat. In adipose tissue, the production of the precursor required for $15 \mathrm{~d}-\mathrm{PGJ}_{2}$ formation, $\mathrm{PGD}_{2}$, was significantly reduced; macrophage-dependent inflammation was also significantly reduced [158]. Moreover, calcitriol has been reported to regulate the expression of several key genes involved in the PG pathway, causing a decrease in PG synthesis [164]. Calcitriol and its analogs have been shown to selectively inhibit the activity of COX-2 [165]. These findings suggest that vitamin D may play a role in modulating the inflammatory process in obesity.

Reactive oxygen species (ROS) are produced by activated phagocytes as a part of their microbicidal activities. An association between ROS and metabolic syndrome has been demonstrated in asymptomatic Japanese men [166]. Diet-induced obesity increases the levels of total and 
individual ROS in the brain and highlights a direct relationship between the amount of adiposity and the level of oxidative stress within the brain [167], suggesting that obesity increases cerebro-cortical ROS and impairs brain function. High-fat diets (HFDs) induce obesity and result in an increase in oxidative stress in adipose tissue. One study reported an increase in body weight after 90 days of HFD and observed that exercise training prevented greater gain. Lipid peroxidation and protein carbonylation increased in fat tissue after HFD and decreased significantly after exercise training [168], suggesting an interaction between ROS and lipolysis. Obesity has been linked to a low-grade pro-inflammatory state, in which impairments in the oxidative stress and antioxidant mechanisms are involved $[169,170]$. The over-expression of manganese superoxide dismutase (MnSOD) ameliorated high-fat diet-induced insulin resistance in rat skeletal muscle [171]. Obese adult rats experienced greater mitochondrial hydrogen peroxide release compared with lean adult rats [172]. Glutathione S-transferase P1 gene polymorphisms increase the susceptibility to and risk of type 2 diabetes mellitus and obesity [173]. Significant impairment in glutathione peroxidase has been observed in response to diet-induced obesity [167]. The suppression of glutathione peroxidase activity was demonstrated in diabetic patients compared to healthy controls, and suppression was observed to occur in a greater degree in obese vs. non-obese diabetics. There were higher levels of oxidative stress in the obese diabetics even after control of hyperglycemia by insulin treatment, suggesting the importance of obesity in contributing to oxidative stress [174]. A significant decrease of all glutathione forms, including the content of total glutathione (GSH) and glutathionylated proteins, has been demonstrated in obese and type 1 diabetic children [175]. Similarly, calcitriol has been reported to exert a receptor-mediated effect on the secretion of $\mathrm{H}_{2} \mathrm{O}_{2}$ by human monocytes [176]. Human monocytes in culture gradually lose their capacity to produce superoxide when stimulated. The addition of calcitriol, lipopolysaccharide or lipoteichoic acid restored the capacity of stimulated monocytes to produce superoxide and increased their oxidative capacity compared with unstimulated monocytes [177]. Calcitriol can also protect nonmalignant prostate cells from oxidative stress-induced cell death by eliminating ROS-induced cellular injuries [178]. Vitamin D metabolites and vitamin $\mathrm{D}$ analogs have been reported to induce lipoxygenase mRNA expression, lipoxygenase activity and ROS in a human bone cell line [179]. In another study, the vitamin D analog (24R)-1,24-dihydroxycholecalciferol prevented neuronal damage caused by hydrogen peroxide-induced toxicity in the SH-SY5Y cell line [144]. Vitamin D can also reduce the extent of lipid peroxidation and can induce SOD activity in a hepatic anti-oxidant system in rats [180]. Astrocytes play a pivotal role in the
CNS detoxification pathways in which GSH is involved in eliminating oxygen and nitrogen reactive species, such as NO. Calcitriol affects this pathway by enhancing intracellular GSH pools and significantly reduces the nitrite production that is induced by LPS [181]. These findings suggest that vitamin $\mathrm{D}$ modulates oxidative stress in obesity.

Nitric oxide synthase (NOS) is an enzyme that is involved in the synthesis of nitric oxide $(\mathrm{NO})$, which regulates a variety of important physiological responses, including cell migration, the immune response, and apoptosis. High fat diets modulate nitric oxide biosynthesis and antioxidant defense in red blood cells in C57BL/6 mice [182], which lead to increasde NO sensitivity in rat coronary arterioles [183]. Platelet NO production has been significantly correlated with BMI, waist circumference, and triglyceride concentrations, thus suggesting an association between increased platelet NO production, obesity, and hypertriglyceridemia, independent of the degree of insulin-resistance [184]. Chronic NOS blockade by LNAME in mice ameliorated high-fat diet-induced adiposity and glucose intolerance, accompanied by reduced adipose inflammation and improved insulin signaling in skeletal muscle, suggesting that endogenous NO plays a modulatory role in the development of obesity-related insulin resistance [185]. Mice deprived of the eNOS and/or nNOS gene exhibit metabolic syndrome, including insulin resistance, hypertension, and dyslipidemia [186]. Inducible NOS (iNOS)-null mice, although protected from obesityrelated insulin resistance, exhibit increased adiposity [187]. Conversely, the activation of $1 \alpha$-hydroxylase in macrophages increases the level of calcitriol, which inhibits the iNOS expression and reduces NO production within LPS-stimulated macrophages [188]. Thus, calcitriol production by macrophages may provide protection against the oxidative injuries that are caused by the NO burst. Calcitriol is known to inhibit LPS-induced immune activation in human endothelial cells [189]. In experimental allergic encephalomyelitis, calcitriol inhibits the expression of iNOS in the rat CNS [190].

\section{Conclusions}

This paper reviewed the relationship between vitamin D and obesity. Genetic studies provide opportunities to determine which proteins link vitamin $\mathrm{D}$ to obesity pathology. Vitamin D is also able to act through numerous non-genomic mechanisms, including protein expression, oxidative stress, inflammation, and cellular metabolism. These findings suggest that vitamin D plays a role in obesity. However, some studies demonstrated no effect of vitamin D on weight change and energy expenditure and little improvement in cardiovascular risks with cholecalciferol [191-194]. Interestingly, Vitamin D is fat-soluble and readily stored in adipose tissue; it is 
sequestered after absorption and stored in tissues such as fat and muscle [195]. This fate of vitamin D has been demonstrated by injecting radio-labeled vitamin $\mathrm{D}_{3}$ into individuals and monitoring the highest levels of biological activity and radioactivity in the fat tissue [196]. In addition, cholecalciferol supplementation has no effect on cytokines and markers of inflammation in obese subjects [197]. Calcitriol, inversely, modulates adipokine expression, inhibits anti-inflammatory cytokine expression, reduces monocyte recruitment by human pre-adipocytes, and restores glucose uptake in adipocytes [198-200]. Calcitriol has a role in human adipose tissue because it is the active form of vitamin $\mathrm{D}_{3}$ metabolite, and VDR receptors present in adipocytes allow the suppression of PTH levels. The PTH excess observed in elderly subjects with both primary and secondary hyperparathyroidism may promote weight gain by impeding catecholamineinduced lipolysis [201]. However, monitoring of serum 25OHD after calcitriol intake is not necessary because calcitriol inhibits the production of serum 25OHD in the liver [202,203]. Taken together, there is widespread evidence from laboratory, animal and genetic studies that calcitriol is active in obesity. Calcitriol therapy in obesity has not been reported whilst the results of trials of cholecalciferol supplementation have so far been limited. Therefore, further investigation of calcitriol in obese patients is needed.

\section{Competing interests}

The authors declare that they have no competing interests.

\section{Authors' contributions}

This work was carried out in collaboration between both authors. Author KL designed the study and wrote the protocol. Author LN managed the

literature searches. All authors read and approved the final manuscript.

Received: 23 March 2013 Accepted: 21 June 2013

Published: 25 June 2013

\section{References}

1. Bell NH, Epstein S, Greene A, Shary J, Oexmann MJ, Shaw S: Evidence for alteration of the vitamin D-endocrine system in obese subjects. J Clin Invest. 1985, 76:370-373.

2. Fung GJ, Steffen $L M$, Zhou X, Harnack $L$, Tang W, et al: Vitamin D intake is inversely related to risk of developing metabolic syndrome in African American and white men and women over 20 y: the coronary artery risk development in young adults study. Am J Clin Nutr. 2012, 96:24-29.

3. Robinson C, Chiang M, Thompson SN, Sondike SB: Occurrence of vitamin D deficiency in pediatric patients at high risk in West Virginia. South Med J. 2012, 105:504-507.

4. Tamer G, Mesci B, Tamer I, Kilic D, Arik S: Is vitamin D deficiency an independent risk factor for obesity and abdominal obesity in women? Endokrynol Pol. 2012, 63:196-201.

5. Josefson JL, Feinglass J, Rademaker AW, Metzger BE, Zeiss DM, et al: Maternal obesity and vitamin D sufficiency Are associated with cord blood vitamin D insufficiency. $J$ Clin Endocrinol Metab 2012. Epub ahead of print.

6. Sulistyoningrum DC, Green TJ, Lear SA, Devlin AM: Ethnic-specific differences in vitamin $\mathrm{D}$ status is associated with adiposity. PLoS One. 2012, 7:e43159.

7. Jungert $A$, Roth $H J$, Neuhäuser-Berthold M: Serum 25-hydroxyvitamin $D_{3}$ and body composition in an elderly cohort from Germany: a crosssectional study. Nutr Metab (Lond) 2012, 9:42.
8. Lee SH, Kim SM, Park HS, Choi KM, Cho GJ, et al: Serum 25-hydroxyvitamin D levels, obesity and the metabolic syndrome among Korean children. Nutr Metab Cardiovasc Dis 2012. Epub ahead of print.

9. Saliba W, Barnett-Griness O, Rennert G: The relationship between obesity and the increase in serum $25(\mathrm{OH}) \mathrm{D}$ levels in response to vitamin $\mathrm{D}$ supplementation. Osteoporos Int 2012. Epub ahead of print

10. Wamberg L, Christiansen T, Paulsen SK, Fisker S, Rask P, Rejnmark L, Richelsen B, Pedersen SB: Expression of vitamin D-metabolizing enzymes in human adipose tissue-the effect of obesity and diet-induced weight loss. Int J Obes (Lond) 2013. 37(5):651-7.

11. Morris KL, Zemel MB: 1,25-Dihydroxyvitamin $\mathrm{D}_{3}$ modulation of adipocyte glucocorticoid function. Obes Res 2005, 13:670-677.

12. Salehpour A, Hosseinpanah F, Shidfar F, Vafa M, Razaghi M, et al: A 12-week double-blind randomized clinical trial of vitamin $D_{3}$ supplementation on body fat mass in healthy overweight and obese women. Nutr J. 2012, 11:78

13. Nagpal J, Pande JN, Bhartia A: A double-blind, randomized, placebocontrolled trial of the short-term effect of vitamin $D_{3}$ supplementation on insulin sensitivity in apparently healthy, middle-aged, centrally obese men. Diabet Med. 2009, 26:19-27.

14. Lương KVQ, Nguyễn LTH: Vitamin D and obesity. Medicinal Chemistry (OMICS) 2012, 2:1.

15. Sato $M$, Hiragun A: Demonstration of 1 alpha,25-dihydroxyvitamin $D_{3}$ receptor-likemolecule in ST 13 and $3 \mathrm{~T} 3 \mathrm{~L} 1$ preadipocytes and its inhibitory effects on preadipocyte differentiation. J Cell Physiol 1988, 135:545-550.

16. Blumberg JM, Tzameli I, Astapova I, Lam FS, Flier JS, Hollenberg AN: Complex role of the vitamin $\mathrm{D}$ receptor and its ligand in adipogenesis in 3T3-L1 cells. J. Biol. Chem. 2006, 281:11205-11213.

17. Fu M, Sun T, Bookout AL, Downes M, Yu RT, et al: A nuclear receptor atlas: 3T3-L1 adipogenesis. Mol Endocrinol. 2005, 19:2437-2450.

18. Imagawa $M$, Tsuchiya $T$, Nishihara T: Identification of inducible genes at the early stage of adipocyte differentiation of 3T3-L1 cells. Biochem Biophy Res Commun. 1999, 254:299-305.

19. Lee $S$, Lee DK, Choi E, Lee JW: Identification of a functional vitamin D response element in the murine Insig-2 promoter and its potential role in the differentiation of 3T3-L1 preadipocytes. Mol Endocrinol. 2005, 19:399-408.

20. Guzey M, Jukic D, Arlotti J, Acquafondata M, Dhir R, Getzenberg RH: Increased apoptosis of periprostattic adipose tissue in VDR null mice. J Cell Biochem. 2004, 93:133-141.

21. Zinzer $\mathrm{GM}$, Welsh JE: Vitamin $\mathrm{D}$ receptor status alters mammary gland morphology and tumorigenesis in MMTV-neu mice. Carcinogenesis. 2004 25:2361-2372

22. Wong $\mathrm{KE}$, Szeto $\mathrm{FL}$, Zhang $\mathrm{W}$, Ye $\mathrm{H}$, et al: Involvement of the vitamin $\mathrm{D}$ receptor in energy metabolism: regulation of uncoupling proteins. Am J Physiol Endocrinol Metab. 2009, 296:E820-E828.

23. Narvaez CJ, Matthews D, Broun E, Chan M, Welsh J: Lean phenotype and resistance to diet-induced obesity in vitamin $D$ receptor knockout mice correlates with induction of uncoupling protein-1 in white adipose tissue. Endocrinology. 2009, 150:651-661.

24. Weber K, Erben RG: Differences in triglyceride and cholesterol metabolism and resistance to obesity in male and female vitamin $D$ receptor knockout mice. J Anim Physiol Anim Nutr (Berl) 2012. doi:10.1111/j.1439-0396.2012.01308.x. [Epub ahead of print].

25. Wong KE, Kong J, Zhang W, Szeto FL, Ye H, et al: Targeted expression of human vitamin $\mathrm{D}$ receptor in adipocytes decreases energy expenditure and induces obesity in mice. J Biol Chem. 2011, 286:33804-33810.

26. Santos BR, Mascarenhas LP, Satler F, Boguszewski MC, Spritzer PM: Vitamin $D$ deficiency in girls from South Brazil: a cross-sectional study on prevalence and association with vitamin $\mathrm{D}$ receptor gene variants. BMC Pediatr. 2012, 12:62

27. Ye WZ, Reis AF, Dubois-Laforgue D, Bellanné-Chantelot C, et al: Vitamin D receptor gene polymorphisms are associated with obesity in type 2 diabetic subjects with early age of onset. Eur J Endocrinol. 2001, 145:181-186.

28. Vasilopoulos Y, Sarafidou T, Kotsa K, Papadimitriou M, Goutzelas Y, et al: VDR Taql is associated with obesity in the Greek population. Gene. 2013, 512:237-239.

29. Binh TQ, Nakahori Y, Hien VT, Khan NC, Lam NT, et al: Correlations between genetic variance and adiposity measures, and gene $\mathrm{x}$ gene interactions for obesity in postmenopausal Vietnamese women. J Genet. 2011, 90:1-9.

30. Filus A, Trzmiel A, Kuliczkowska-Płaksej J, Tworowska U, Jedrzejuk D, et al: Relationship between vitamin D receptor Bsml and Fokl polymorphisms 
and anthropometric and biochemical parameters describing metabolic syndrome. Aging Male. 2008, 11:134-139.

31. Creely SJ, McTernan PG, Kusminski CM, Fisher M, Da Silva NF, et al: Lipopolysaccharide activates an innate immune system response in human adipose tissue in obesity and type 2 diabetes. Am J Physiol Endocrinol Metab. 2007, 292:E740-E747.

32. Kim SJ, Choi Y, Choi YH, Park T: Obesity activates toll-like receptormediated proinflammatory signaling cascades in the adipose tissue of mice. J Nutr Biochem. 2012, 23:113-122.

33. Vitseva Ol, Tanriverdi K, Tchkonia TT, Kirkland JL, McDonnell ME, et al: Inducible Toll-like receptor and NF-kappaB regulatory pathway expression in human adipose tissue. Obesity (Silver Spring). 2008, 16:932-937.

34. Davis JE, Gabler NK, Walker-Daniels J, Spurlock ME: TIr-4 deficiency selectively protects against obesity induced by diets high in saturated fat. Obesity (Silver Spring). 2008, 16:1248-1255.

35. Tsukumo DM, Carvalho-Filho MA, Carvalheira JB, Prada PO, Hirabara SM, et al: Loss-of-function mutation in Toll-like receptor 4 prevents dietinduced obesity and insulin resistance. Diabetes. 2007, 56:1986-1998.

36. Suganami T, Mieda T, Itoh M, Shimoda Y, Kamei Y, Ogawa Y: Attenuation of obesity-induced adipose tissue inflammation in $\mathrm{C} 3 \mathrm{H} / \mathrm{HeJ}$ mice carrying a Toll-like receptor 4 mutation. Biochem Biophys Res Commun. 2007, 354:45-49.

37. Caricilli AM, Nascimento PH, Pauli JR, Tsukumo DM, Velloso LA, et al: Inhibition of toll-like receptor 2 expression improves insulin sensitivity and signaling in muscle and white adipose tissue of mice fed a high-fat diet. J Endocrinol. 2008, 199:399-406.

38. Jermendy A, Korner A, Kovacs M, Kaszas E, Balázsovics J, et al: Association between toll-like receptor polymorphisms and serum levels of tumor necrosis factor-alpha and its soluble receptors in obese children. Med Sci Monit. 2010, 16:CR180-CR185.

39. Roth CL, Elfers CT, Figlewicz DP, Melhorn SJ, Morton GJ, et al: Vitamin D deficiency in obese rats exacerbates NAFLD and increases hepatic resistin and toll-like receptor activation. Hepatol. 2012, 55:1103-1111.

40. Sadeghi K, Wessner B, Laggner U, Ploder M, Tamandl D, et al: Vitamin $D_{3}$ down-regulates monocyte TLR expression and triggers hyporesponsiveness to pathogen-associated molecular patterns. Eur J Immunol. 2006, 36:361-370.

41. Dickie L, Church L, Coulthard L, Mathews R, Emery P, McDermott M: Vitamin $D_{3}$ downregulates intracellular toll-like receptor 9 expression and toll-like receptor 9-induced IL-6 production in human monocytes. Rheumatol. 2010, 48:1466-1471.

42. Liu PT, Stenger S, Li H, Wenzel L, Tan BH, et al: Toll-like receptor triggering of a vitamin D-mediated human antimicrobial response. Science. 2006, 311:1770-1773.

43. Johnston Cl: Tissue angiotensin converting enzyme in cardiac and vascular hypertrophy, repair, and remodeling. Hypertension. 1994, 23:258-268.

44. Karlsson C, Lindell K, Ottosson M, Sjöström L, Carlsson B, Carlsson LM: Human adipose tissue expresses angiotensinogen and enzymes required for its conversion to angiotensin II. J Clin Endocrinol Metab. 1998, 83:3925-3929.

45. Engeli S, Gorzelniak K, Kreutz R, Runkel N, Distler A, Sharma AM: Co-expression of renin-angiotensin system genes in human adipose tissue. J Hypertens. 1999, 17:555-560.

46. Fowler JD, Johnson ND, Haroldson TA, Brintnall JA, Herrera JE, et al: Regulated renin release from 3T3-L1 adipocytes. Am J Physiol Endocrinol Metab. 2009, 296:E1383-E1391.

47. Achard V, Boullu-Ciocca S, Desbriere R, Nguyen G, Grino M: Renin receptor expression in human adipose tissue. Am J Physiol Regul Integr Comp Physiol. 2007, 292:R274-R282

48. Ho JT, Keogh JB, Bornstein SR, Ehrhart-Bornstein M, Lewis JG, et al: Moderate weight loss reduces renin and aldosterone but does not influence basal or stimulated pituitary-adrenal axis function. Horm Metab Res. 2007, 39:694-699.

49. Jones BH, Standridge MK, Moustaid N: Angiotensin II increases lipogenesis in 3T3-L1 and human adipose cells. Endocrinology. 1997, 138:1512-1519.

50. Massiera F, Seydoux J, Geloen A, Quignard-Boulange A, Turban S, et al: Angiotensinogen-deficient mice exhibit impairment of diet-induced weight gain with alteration in adipose tissue development and increased locomotor activity. Endocrinology. 2001, 142:5220-5225.

51. Yvan-Charvet L, Even P, Bloch-Faure M, Guerre-Millo M, Moustaid-Moussa N, et al: Deletion of the angiotensin type 2 receptor (AT2R) reduces adipose cell size and protects from diet-induced obesity and insulin resistance. Diabetes. 2005, 54:991-999.
52. Iwai $M$, Tomono $Y$, Inaba $S$, Kanno $H$, Senba I, et al: AT2 receptor deficiency attenuates adipocyte differentiation and decreases adipocyte number in atherosclerotic mice. Am J Hypertens. 2009, 22:784-791.

53. Matsushita K, Wu Y, Okamoto Y, Pratt RE, Dzau VJ: Local renin angiotensin expression regulates human mesenchymal stem cell differentiation to adipocytes. Hypertension. 2006, 48:1095-1102.

54. Vaziri ND, Xu ZG, Shahkarami A, Huang KT, Rodríguez-lturbe B, Natarajan R: Role of AT-1 receptor in regulation of vascular MCP-1, IL-6, PAI-1, MAP kinase, and matrix expressions in obesity. Kidney Int. 2005, 68:2787-2793.

55. Toblli JE, Muñoz MC, Cao G, Mella J, Pereyra L, Mastai R: ACE inhibition and AT1 receptor blockade prevent fatty liver and fibrosis in obese Zucker rats. Obesity (Silver Spring). 2008, 16:770-776.

56. Procopciuc LM, Sitar-Tăut A, Pop D, Sitar-Tăut DA, Olteanu I, Zdrenghea D: Renin angiotensin system polymorphisms in patients with metabolic syndrome (MetS). Eur J Intern Med. 2010, 21:414-418.

57. Hamada T, Kotani K, Nagai N, Tsuzaki K, Sano Y, et al: Genetic polymorphisms of the renin-angiotensin system and obesity-related metabolic changes in response to low-energy diets in obese women. Nutrition. 2011, 27:34-39.

58. Mehri S, Mahjoub S, Hammami S, Zaroui A, Frih A, et al: Renin-angiotensin system polymorphisms in relation to hypertension status and obesity in a Tunisian population. Mol Biol Rep. 2012, 39:4059-4065.

59. Strazzullo P, lacone R, lacoviello L, Russo O, Barba G, et al: Genetic variation in the renin-angiotensin system and abdominal adiposity in men: the Olivetti prospective heart study. Ann Intern Med. 2003, 138:17-23.

60. Wacker MJ, Godard MP, McCabe EH, Donnelly JE, Kelly JK: Sex difference in the association of the angiotensin converting enzyme I/D polymorphism and body mass index. Med Sci Monit. 2008, 14:CR353-CR357.

61. Kota SK, Kota SK, Jammula S, Meher LK, Panda S, et al: Renin-angiotensin system activity in vitamin $D$ deficient, obese individuals with hypertension: An urban Indian study. Indian J Endocrinol Metab. 2011, 15(Suppl 4):S395-S401.

62. Tomaschitz A, Pilz S, Ritz E, Grammer T, Drechsler C, Boehm BO, März W: Independent association between 1,25-dihydroxyvitamin D, 25hydroxyvitamin $\mathrm{D}$ and the renin-angiotensin system: the Ludwigshafen risk and cardiovascular health (LURIC) study. Clin Chim Acta. 2010, 411:1354-1360

63. Xiang W, Kong J, Chen S, Cao L, Qiao G, et al: Cardiac hypertrophy in vitamin $D$ receptor knockout mice: role of the systemic and cardiac renin-angiotensin systems. Am J Phys Endocrinol Met. 2005, 288:E125-E132.

64. Zhou C, Lu F, Cao K, Xu D, Goltzman D, Miao D: Calcium-independent and $1,25(\mathrm{OH})_{2} \mathrm{D}_{3}$-dependent regulation of the renin-angiotensin system in 1alpha-hydroxylase knockout mice. Kidney Int. 2008, 74:170-179.

65. Kong J, Qiao G, Zhang Z, Liu SQ, Li YC: Targeted vitamin D receptor expression in juxtaglomerular cells suppresses renin expression independent of parathyroid hormone and calcium. Kidney Int. 2008, 74:1577-1581.

66. Yuan W, Pan W, Kong J, Zheng W, Szeto F, et al: 1,25-dihydroxyvitamin $D_{3}$ suppresses renin gene transcription by blocking the activity of the cyclic AMP response element in the renin gene promoter. J Biol Chem. 2007, 282:29821-29830.

67. Higiwara $H$, Furuhashi $H$, Nakaya $K$, Nakamura $Y$ : Effects of vitamin $D_{3}$ and related compounds on angiotensin converting activity of endothelial cells and on release of plasminogen activator from them. Chem Pharm Bull. 1988, 36:4858-4864.

68. Vaidya A, Forman JP, Williams JS: Vitamin D and the vascular sensitivity to angiotensin II in obese Caucasians with hypertension. $J$ Hum Hypertens. 2011, 25:672-678.

69. Vaidya A, Sun B, Larson C, Forman JP, Williams JS: Vitamin $D_{3}$ therapy corrects the tissue sensitivity to angiotensin ii akin to the action of a converting enzyme inhibitor in obese hypertensives: an interventional study. J Clin Endocrinol Metab. 2012, 97:2456-2465.

70. Zechner R, Moser R, Newman TC, Fried SK, Breslow JL: Apolipoprotein E gene expression in mouse 3T3-L1 adipocytes and human adipose tissue and its regulation by differentiation and lipid content. J Biol Chem. 1991, 266:10583-10588.

71. Huang ZH, Reardon CA, Mazzone T: Endogenous ApoE expression modulates adipocyte triglyceride content and turnover. Diabetes. 2006, 55:3394-3402

72. Rao P, Huang ZH, Mazzone T: Angiotensin II regulates adipocyte apolipoprotein E expression. J Clin Endocrinol Metab. 2007, 92:4366-4372.

73. Huang ZH, Gu D, Mazzone T: Role of adipocyte-derived apoE in modulating adipocyte size, lipid metabolism, and gene expression in vivo. Am J Physiol Endocrinol Metab. 2009, 296:E1110-E1119. 
74. Carmel JF, Tarnus E, Cohn JS, Bourdon E, Davignon J, Bernier L: High expression of apolipoprotein E impairs lipid storage and promotes cell proliferation in human adipocytes. J Cell Biochem. 2009, 106:608-617.

75. VanEck M, Herijgers N, Yates J, Pearce NJ, Hoogerbrugge PM, Berkel TJV: Bone marrow transplantation in apolipoprotein E-deficient mice. Effect of apoE gene dosage on serum lipid concentrations, betaVLDL catabolism, and atherosclerosis. Arteriosd Thromb Vasc Biol 1997, 17:3117-3126.

76. Atkinson RD, Coenen KR, Plummer MR, Gruen ML, Hasty AH: Macrophagederived apolipoprotein $\mathrm{E}$ ameliorates dyslipidemia and atherosclerosis in obese apolipoprotein E-deficient mice. Am J Physiol Endocrinol Metab. 2008, 294:E284-E290.

77. Kuhel DG, Konaniah ES, Basford JE, McVey C, Goodin CT, Chatterjee TK, Weintraub NL, Hui DY: Apolipoprotein E2 accentuates postprandial inflammation and diet-induced obesity to promote hyperinsulinemia in mice. Diabetes 2012. Epub ahead of print.

78. Huang ZH, Maeda N, Mazzone T: Expression of the human apoE2 isoform in adipocytes: altered cellular processing and impaired adipocyte lipogenesis. J Lipid Res. 2011, 52:1733-1741.

79. Huebbe P, Nebel A, Siegert S, Moehring J, Boesch-Saadatmandi C, et al: APOE $\varepsilon 4$ is associated with higher vitamin D levels in targeted replacement mice and humans. FASEB J. 2011, 25:3262-3270.

80. Shiraki M, Shiraki Y, Aoki C, Hosoi T, Inoue S, et al: Association of bone mineral density with apolipoprotein E phenotype. J Bone Miner Res. 1997, 12:1438-1445.

81. Gerdes LU, Vestergaard P, Hermann AP, Mosekilde L: Regional and hormonedepenpent effects of apolipoprotein E genotype on changes in bone mineral in perimenopausal women. J Bone Miner Res. 2001, 16:1906-1916.

82. Jouni ZE, McNamara DJ: Lipoprotein receptors of HL-60 macrophages. Effect of differentiation with tetramyristic phorbol acetate and 1,25 dihydroxyvitamin $D_{3}$. Arterioscler Thromb. 1991, 11:995-1006.

83. Husain K, Suarez E, Isidro A, Ferder L: Effects of paricalcitol and enalapril on atherosclerotic injury in mouse aortas. Am J Nephrol. 2010, 32:296-304.

84. Becker LE, Koleganova N, Piecha G, Noronha IL, Zeier M, et al: Effects of paricalcitol and calcitriol on aortic wall remodeling in uninephrectomized ApoE knockout mice. Am J Physiol Renal Physiol. 2011, 300:F772-F782.

85. Ponda MP, Huang X, Odeh MA, Breslow JL, Kaufman HW: Vitamin D may not improve lipid levels: a serial clinical laboratory data study. Circulation. 2012, 126:270-277

86. Wang $\mathrm{H}$, Xia N, Yang $\mathrm{Y}$, Peng DQ: Influence of vitamin D supplementation on plasma lipid profiles: a meta-analysis of randomized controlled trials. Lipids Health Dis. 2012, 11:42

87. Loebig M, Klement J, Schmoller A, Betz S, Heuck N, et al: Evidence for a relationship between VEGF and BMI independent of insulin sensitivity by glucose clamp procedure in a homogenous group healthy young men. PLoS One. 2010, 5:e12610.

88. Ledoux S, Queguiner I, Msika S, Calderari S, Rufat P, et al: Angiogenesis associated with visceral and subcutaneous adipose tissue in severe human obesity. Diabetes. 2008, 57:3247-3257.

89. Yamaguchi M, Matsumoto F, Bujo H, Shibasaki M, Takahashi K, et al: Revascularization determines volume retention and gene expression by fat grafts in mice. Exp Biol Med (Maywood). 2005, 230:742-748.

90. Rupnick MA, Panigrahy D, Zhang CY, Dallabrida SM, Lowell BB, et al: Adipose tissue mass can be regulated through the vasculature. Proc Natl Acad Sci U S A. 2002, 99:10730-10735.

91. Miyazawa-Hoshimoto S, Takahashi K, Bujo H, Hashimoto N, Yagui K, Saito Y: Roles of degree of fat deposition and its localization on VEGF expression in adipocytes. Am J Physiol Endocrinol Metab. 2005, 288:E1128-E1136.

92. Miyazawa-Hoshimoto S, Takahashi K, Bujo H, Hashimoto N, Saito Y: Elevated serum vascular endothelial growth factor is associated with visceral fat accumulation in human obese subjects. Diabetologia. 2003, 46:1483-1488.

93. Kawamura T, Murakami K, Bujo $\mathrm{H}$, Unoki $\mathrm{H}$, Jiang M, et al: Matrix metalloproteinase-3 enhances the free fatty acids-induced VEGF expression in adipocytes through toll-like receptor 2. Exp Biol Med (Maywood). 2008 , 233:1213-1221

94. Hagberg CE, Falkevall A, Wang X, Larsson E, Huusko J, et al: Vascular endothelial growth factor B controls endothelial fatty acid uptake. Nature. 2010, 464:917-921.

95. Tam J, Duda DG, Perentes JY, Quadri RS, et al: Blockade of VEGFR2 and not VEGFR1 can limit diet-induced fat tissue expansion: role of local versus bone marrow-derived endothelial cells. PLoS One. 2009, 4:e4974.

96. García de la Torre N, Rubio MA, Bordiú E, Cabrerizo L, Aparicio E, et al: Effects of weight loss after bariatric surgery for morbid obesity on vascular endothelial growth factor-A, adipocytokines, and insulin. J Clin Endocrinol Metab 2008, 93:4276-4281.

97. Belo VA, Souza-Costa DC, Luizon MR, Izidoro-Toledo TC, Lanna CM, et al: Vascular endothelial growth factor haplotypes associated with childhood obesity. DNA Cell Biol. 2011, 30:709-714

98. Mantell D, Owens P, Bundred N, Mawer E, Canfield A: 1a,25dihydroxyvitamin $D_{3}$ inhibits angiogenesis in vitro and in vivo. Circ Res. 2000, 87:214-220.

99. Gruber H, Hoelscher G, Ingram J, Chow Y, Loffler B, Hanley E Jr: 1a,25dihydroxyvitamin $D_{3}$ inhibits proliferation and decreases production of monocyte chemoattractant protein-1, thrombopoietin, VEGF, and angiogenin by human annulus cells in vitro. Spine. 2008, 33:755-765.

100. Albert D, Scheef E, Wang S, Mehraein F, Darjatmoko S, Sorenson C, Sheibani $\mathrm{N}$ : Calcitriol is a potent inhibitor of retinal neovascularization. Invest Ophthalmol Vis Sci. 2007, 48:2327-2334.

101. Nakagawa K, Sasaki Y, Kato S, Kubodera N, Okano T: 22-Oxa-1a,25dihydroxyvitamin $D_{3}$ inhibits metastasis and angiogenesis in lung cancer. Carcinogenesis. 2005, 26:1044-1054.

102. Ben-Shoshan M, Amir S, Dang D, Dang L, Weisman Y, Mabjeesh N: 1a,25dihydroxyvitamin $D_{3}$ (Calcitriol) inhibits hypoxia-inducible factor-1/ vascular endothelial growth pathway in human cancer cells. Mol Cancer Ther. 2007, 6:1433-1439.

103. Kisker O, Onizuka S, Becker CM, Fannon M, Flynn E, et al: Vitamin D binding protein-macrophage activating factor (DBP-maf) inhibits angiogenesis and tumor growth in mice. Neoplasia. 2003, 5:32-40.

104. Kalkunte S, Brard L, Granai C, Swamy N: Inhibition of angiogenesis by vitamin D-binding protein: characterization of anti-endothelial activity of DBP-maf. Angiogenesis. 2005, 8:349-360.

105. Krishnakumar R, Kraus WL: The PARP side of the nucleus: molecular actions, physiological outcomes, and clinical targets. Mol Cell. 2010, 39:8-24.

106. Erener S, Hesse M, Kostadinova R, Hottiger MO: Poly(ADP-ribose) polymerase-1 (PARP1) controls adipogenic gene expression and adipocyte function. Mol Endocrinol. 2012, 26:79-86.

107. Devalaraja-Narashimha K, Padanilam BJ: PARP1 deficiency exacerbates diet-induced obesity in mice. J Endocrinol. 2010, 205:243-252.

108. Wang ZQ, Auer B, Stingl L, Berghammer H, Haidacher D, et al: Mice lacking ADPRT and poly(ADP-ribosyl)ation develop normally but are susceptible to skin disease. Genes Dev. 1995, 9:509-520.

109. Cantó C, Houtkooper RH, Pirinen E, Youn DY, Oosterveer MH, et al: The NAD precursor nicotinamide riboside enhances oxidative metabolism and protects against high-fat diet-induced obesity. Cell Metab. 2012, 15:838-847.

110. Bai $P$, Canto $C$, Oudart H, Brunyánszki A, Cen Y, et al: PARP-1 inhibition increases mitochondrial metabolism through SIRT1 activation. Cell Metabolism 2011:13.

111. de Murcia JM, Niedergang C, Trucco C, Ricoul M, Dutrillaux B, et al: Requirement of poly(ADP-ribose) polymerase in recovery from DNA damage in mice and in cells. Proc Natl Acad Sci U S A. 1997, 94:7303-7307.

112. Bai P, Houten SM, Huber A, Schreiber V, Watanabe M, et al: Poly(ADPribose) polymerase-2 [corrected] controls adipocyte differentiation and adipose tissue function through the regulation of the activity of the retinoid $\mathrm{X}$ receptor/peroxisome proliferator-activated receptor-gamma [corrected] heterodimer. J Biol Chem. 2007, 282:37738-37746.

113. Bai P, Canto C, Brunyánszki A, Huber A, Szántó M, et al: PARP-2 regulates SIRT1 expression and whole-body energy expenditure. Cell Metab. 2011, 13:450-460

114. Yeh TY, Beiswenger KK, Li P, Bolin KE, Lee RM, et al: Hypermetabolism, hyperphagia, and reduced adiposity in tankyrase-deficient mice. Diabetes. 2009, 58:2476-2485.

115. Bhatia M, Kirkland JB, Mecking-Gill KA: Modulation of poly(ADP-ribose) polymerase during neurophilic and monocytic differentiation of promyelocytic (NB4) and myelocytic (HL-60) leakaemia cells. Biochemical Journal. 1995, 308:131-137.

116. Mabley JG, Wallace R, Pacher P, Murphy K, Szab C: Inhibition of poly (adenosine diphosphate-ribose) polymerase by the active form of vitamin D. International Journal of Molecular Medicine 2007, 9(6):947-952

117. Shen M, Yen A: Nicotinamide cooperates with retinoic acid and 1,25dihydroxyvitamin $D_{3}$ to regulate cell differentiation and cell cycle arrest of human myeloblastic leukemia cells. Oncology 2009, 76:91-100.

118. Moore M, Piazza A, Nolan Y, Lynch MA: Treatment with dexamethasone and vitamin $D_{3}$ attenuates neuroinflammatory age-related changes in rat hippocampus. Synapse. 2007, 61:851-861. 
119. Bouloumié $A$, Sengenès $C$, Portolan $G$, et al: Adipocyte produces matrix metalloproteinases 2 and 9: involvement in adipose differentiation. Diabetes. 2001, 50:2080-2086.

120. Miksztowicz V, Siseles N, Machulsky NF, Schreier L, Berg G: Increase in MMP-2 activity in overweight and obese women is associated with menopausal status. Climacteric. 2012, 15:602-606.

121. Laimer M, Kaser S, Kranebitte M, Sandhofer A, Muhlmann G, et al: Effect of pronounced weight loss on the nontraditional cardiovascular risk marker matrix metalloproteinase-9 in middle-aged morbidly obese women. Int J Obes. 2005, 29:498-501.

122. Garvin P, Nilsson L, Carstensen J, Jonasson L, Kristenson M: Circulating matrix metalloproteinase- 9 is associated with cardiovascular risk factors in a middle-aged normal population. PLoS One. 2008, 3:e1774.

123. Głowińska-Olszewska B, Urban M: Elevated matrix metalloproteinase 9 and tissue inhibitor of metalloproteinase 1 in obese children and adolescents. Metabolism. 2007, 56:799-805.

124. Belo VA, Souza-Costa DC, Lana CM, Caputo FL, Marcaccini AM, et al: Assessment of matrix metalloproteinase (MMP)-2, MMP-8, MMP-9, and their inhibitors, the tissue inhibitors of metalloproteinase (TIMP)-1 and TIMP-2 in obese children and adolescents. Clin Biochem. 2009, 42:984-990.

125. Morgan AR, Han DY, Thompson JM, Mitchell EA, Ferguson LR: Analysis of MMP2 promoter polymorphisms in childhood obesity. BMC Res Notes. 2011, 4:253.

126. Andrade VL, Fernandes KS, Bosco AA, Tanus-Santos JE, Sandrim VC: Functional polymorphism located in MMP-9 gene promoter is strongly associated with obesity. DNA Cell Biol. 2012, 31:1054-1057.

127. Belo VA, Souza-Costa DC, Luizon MR, Lanna CM, Carneiro PC, et al: Matrix metalloproteinase-9 genetic variations affect MMP-9 levels in obese children. Int J Obes (Lond). 2012, 36:69-75.

128. Sundar I, Hwang J, Wu S, Sun J, Rahman I: Deletion of vitamin D receptor leads to premature emphysema/COPD by increased matrix metalloproteinase and lymphoid aggregates formation. Biochem Biophys Res Commun. 2011, 406:127-133.

129. Timms P, Mannan N, Hitman G: Circulating MMP9, vitamin D and variation in the TIMP-1 response with VDR genotype: mechanisms for inflammatory damage in chronic disorders? Q J Med. 2002, 95:787-796.

130. Dean DD, Schwartz Z, Schmitz J, Muniz OE, Lu Y, et al: Vitamin D regulation of metalloproteinase activity in matrix vesicles. Connect Tissue Res. 1996, 35:331-336.

131. Bahar-shany K, Ravid A, Koren R: Upregulation of MMP-production by TNFalpha in keratinocytes and its attenuation by vitamin D. J Cell Physiol. 2010, 222:729-737.

132. Lacraz S, Dayer J, Nicod L, Welgus H: 1,25-dihydroxyvitamin $D_{3}$ dissociates production of interstitial collagenase and 92-kDa gelatinase in human mononuclear phagocytes. J Biol Chem. 1994, 269:6485-6490.

133. Hipskind RA, Bilbe G: MAP kinase signaling cascades and gene expression in osteoblasts. Front Biosci. 1998, 3:d804-d816.

134. Aouadi M, Jager J, Laurent K, Gonzalez T, Cormont M, et al: p38MAP Kinase activity is required for human primary adipocyte differentiation. FEBS Lett. 2007, 581:5591-5596.

135. Roth RJ, Le AM, Zhang L, Kahn M, Samuel VT, et al: MAPK phosphatase-1 facilitates the loss of oxidative myofibers associated with obesity in mice. J Clin Invest. 2009, 119:3817-3829.

136. Wu JJ, Roth RJ, Anderson EJ, Hong EG, Lee MK, et al: Mice lacking MAP kinase phosphatase- 1 have enhanced MAP kinase activity and resistance to diet-induced obesity. Cell Metab. 2006, 4:61-73.

137. Ito A, Suganami T, Miyamoto Y, Yoshimasa Y, Takeya M, et al: Role of MAPK phosphatase- 1 in the induction of monocyte chemoattractant protein-1 during the course of adipocyte hypertrophy. J Biol Chem. 2007, 282:25445-25452.

138. Katiyar SK, Meeran SM: Obesity increases the risk of UV radiation-induced oxidative stress and activation of MAPK and NF-kappaB signaling. Free Radic Biol Med. 2007, 42:299-310.

139. Aouadi M, Laurent $K$, Prot M, Le Marchand-Brustel $Y$, Binétruy B, Bost F: Inhibition of p38MAPK increases adipogenesis from embryonic to adult stages. Diabetes. 2006, 55:281-289.

140. Rask-Andersen M, Jacobsson JA, Moschonis G, Ek AE, Chrousos GP, et al: The MAP2K5-linked SNP rs2241423 is associated with BMI and obesity in two cohorts of Swedish and Greek children. BMC Med Genet. 2012, 13:36

141. Sun C, Qi R, Wang L, Yan J, Wang Y: p38 MAPK regulates calcium signalmediated lipid accumulation through changing VDR expression in primary preadipocytes of mice. Mol Biol Rep. 2012, 39:3179-3184.
142. Ravid A, Rubinstein E, Gamady A, Rotem C, Liberman UA, Koren R: Vitamin $D$ inhibits the activation of stress-activated protein kinases by physiological and environmental stresses in keratinocytes. J Endocrinol. 2002, 173:525-532.

143. Zhang Y, Leung DY, Richers BN, Liu Y, Remigio LK, et al: Vitamin D inhibits monocyte/macrophage proinflammatory cytokine production by targeting MAPK phosphatase-1. J Immunol. 2012, 188:2127-2135.

144. Tetich M, Kutner A, Leskiewicz M, Budziszewska B, Lasoń W: Neuroprotective effects of (24R)-1,24-dihydroxycholecalciferol in human neuroblastoma SH-SY5Y cell line. J Steroid Biochem Mol Biol. 2004, 89-90:365-370

145. Liakhovich AV, Aksenov NL, Tuokhima P, Mikhel'son VM: Long-term action of vitamin D suppresses the estradiol-induced activity of erk-1 MAPK and proliferation of MCF-7 and LNCaP cancer cells. Tsitologiia 2000, 42:977-982. Article in Russian.

146. Jiang F, Lim HK, Morris MJ, Prior L, Velkoska E, et al: Systemic upregulation of NADPH oxidase in diet-induced obesity in rats. Redox Rep. 2011, 16:223-229.

147. Silver AE, Beske SD, Christou DD, Donato AJ, Moreau KL, et al: Overweight and obese humans demonstrate increased vascular endothelial NAD(P)H oxidase-p47(phox) expression and evidence of endothelial oxidative stress. Circulation. 2007, 115:627-637.

148. Mouche S, Mkaddem SB, Wang W, Katic M, Tseng YH, et al: Reduced expression of the NADPH oxidase NOX4 is a hallmark of adipocyte differentiation. Biochim Biophys Acta. 2007, 1773:1015-1027.

149. Schröder K, Wandzioch K, Helmcke I, Brandes RP: Nox4 acts as a switch between differentiation and proliferation in preadipocytes. Arterioscler Thromb Vasc Biol. 2009, 29:239-245.

150. Li Y, Mouche S, Sajic T, Veyrat-Durebex C, Supale R, et al: Deficiency in the NADPH oxidase 4 predisposes towards diet-induced obesity. Int J Obes (Lond). 2012, 36:1503-1513.

151. Kanda Y, Hinata T, Kang SW, Watanabe Y: Reactive oxygen species mediate adipocyte differentiation in mesenchymal stem cells. Life Sci. 2011, 89:250-258.

152. Yuan $H$, Zhang $X$, Huang $X$, Lu $Y$, Tang $W$, et al: NADPH oxidase 2-derived reactive oxygen species mediate FFAs-induced dysfunction and apoptosis of $\beta$-cells via JNK, p38 MAPK and p53 pathways. PLoS One. 2010, 5:e15726.

153. Hashizume K, Suzuki S, Ichikawa K, Takeda T, Kobayashi M: Effect of active vitamin $\mathrm{D}_{3}$ on the levels of NADPH-dependent cytosolic 3,5,3'-triiodo-Lthyronine-binding protein. Biochem Biophys Res Commun. 1991, 177:388-394.

154. Stio M, Lunghi B, lantomasi T, Vincenzini MT, Treves C: Effect of vitamin D deficiency and 1,25-dihydroxyvitamin $D_{3}$ on rat heart metabolism. J Mol Cell Cardiol. 1994, 26:1421-1428.

155. Bachelet M, Bader C, Merlot AM, Laborde K, Snarska J, Ulmann A: Cellular utilization of cytosolic NADPH in kidney and liver cells from rats fed a normal or a vitamin D-deficient diet. Cell Biochem Funct. 1983, 1:25-29.

156. Husain K, Ferder L, Mizobuchi M, Finch J, Slatopolsky E: Combination therapy with paricalcitol and enalapril ameliorates cardiac oxidative injury in uremic rats. Am J Nephrol. 2009, 29:465-472.

157. Fujitani Y, Aritake K, Kanaoka Y, Goto T, Takahashi N, et al: Pronounced adipogenesis and increased insulin sensitivity caused by overproduction of prostaglandin $D_{2}$ in vivo. FEBS J. 2010, 277:1410-1419.

158. Ghoshal S, Trivedi DB, Graf GA, Loftin CD: Cyclooxygenase-2 deficiency attenuates adipose tissue differentiation and inflammation in mice. J Biol Chem. 2011, 286:889-898

159. Casimir DA, Miller CW, Ntambi JM: Preadipocyte differentiation blocked by prostaglandin stimulation of prostanoid FP2 receptor in murine 3T3-L1 cells. Differentiation. 1996, 60:203-210.

160. Serrero G, Lepak NM: Prostaglandin $F_{2 a}$ a receptor (FP receptor) agonists are potent adipose differentiation inhibitors for primary culture of adipocyte precursors in defined medium. Biochem Biophys Res Commun. 1997, 233:200-202

161. Fujimori $K$, Ueno T, Amano F: Prostaglandin $F_{2 a}$ suppresses early phase of adipogenesis, but is not associated with osteoblastogenesis in mouse mesenchymal stem cells. Prostaglandins Other Lipid Mediat. 2010, 93:52-59.

162. Henkel J, Frede K, Schanze N, Vogel H, Schürmann A, et al: Stimulation of fat accumulation in hepatocytes by $\mathrm{PGE}_{2}$-dependent repression of hepatic lipolysis, $\beta$-oxidation and VLDL-synthesis. Lab Invest. 2012, 92:1597-1606.

163. Subbaramaiah K, Morris PG, Zhou XK, Morrow M, Du B, et al: Increased levels of COX-2 and prostaglandin E2 contribute to elevated aromatase expression in inflamed breast tissue of obese women. Cancer Discov. 2012, 2:356-365. 
164. Moreno J, Krishnan AV, Swami S, Nonn L, Peehl DM, Feldman D: Regulation of prostaglandin metabolism by calcitriol attenuates growth stimulation in prostate cancer cells. Cancer Research. 2005, 65:7917-7925.

165. Aparna R, Subhashini J, Roy KR, Reddy GS, Robinson M, et al: Selective inhibition of cyclooxygenase-2 (COX-2) by 1 a,25-dihydroxy- 16-ene-23yne-vitamin $D_{3}$, a less calcemic vitamin D analog. J Cell Biochem. 2008, 104:1832-1842.

166. Kotani K, Taniguchi N: The association between reactive oxygen metabolites and metabolic syndrome in asymptomatic Japanese men. J Clin Med Res. 2011, 3:247-251.

167. Freeman LR, Zhang L, Nair A, Dasuri K, Francis J, Fernandez-Kim SO, BruceKeller AJ, Keller JN: Obesity increases cerebrocortical reactive oxygen species and impairs brain function. Free Radic Biol Med 2013, 56:226-33.

168. de Farias JM, Bom KF, Tromm CB, Luciano TF, Marques SO, et al: Effect of physical training on the adipose tissue of diet-induced obesity mice: interaction between reactive oxygen species and lipolysis. Horm Metab Res 2012. Epub ahead of print.

169. Bondia-Pons I, Ryan L, Martinez JA: Oxidative stress and inflammation interactions in human obesity. J Physiol Biochem. 2012, 68:701-711.

170. Codoñer-Franch P, Valls-Bellés V, Arilla-Codoñer A, Alonso-Iglesias E: Oxidant mechanisms in childhood obesity: the link between inflammation and oxidative stress. Trans/ Res. 2011, 158:369-384.

171. Boden MJ, Brandon AE, Tid-Ang JD, Preston E, Wilks D, et al: Overexpression of manganese superoxide dismutase ameliorates highfat diet-induced insulin resistance in rat skeletal muscle. Am J Physiol Endocrinol Metab. 2012, 303:E798-E805.

172. Hey-Mogensen M, Jeppesen J, Madsen K, Kiens B, Franch J: Obesity augments the age-induced increase in mitochondrial capacity for $\mathrm{H}_{2} \mathrm{O} 2$ release in Zucker fatty rats. Acta Physiol (Oxf). 2012, 204:354-361.

173. Amer MA, Ghattas MH, Abo-Elmatty DM, Abou-El-Ela SH: Evaluation of glutathione S-transferase P1 genetic variants affecting type- 2 diabetes susceptibility and glycemic control. Arch Med Sci. 2012, 8:631-636.

174. Goyal R, Singhai M, Faizy AF: Glutathione peroxidase activity in obese and nonobese diabetic patients and role of hyperglycemia in oxidative stress. J Midlife Health. 2011, 2:72-76.

175. Pastore A, Ciampalini P, Tozzi G, Pecorelli L, Passarelli C, et al: All glutathione forms are depleted in blood of obese and type 1 diabetic children. Pediatr Diabetes. 2012, 13:272-277.

176. Gluck WL, Weinberg JB: 1 alpha,25 Dihydroxyvitamin $D_{3}$ and mononuclear phagocytes: enhancement of mouse macrophage and human monocyte hydrogen peroxide production without alteration of tumor cytolysis. J Leukoc Biol. 1987, 42:498-503.

177. Cohen MS, Mesler DE, Snipes RG, Gray TK: 1,25-Dihydroxyvitamin $D_{3}$ activates secretion of hydrogen peroxide by human monocytes. J Immunol. 1986, 136:1049-1053.

178. Levy $\mathrm{R}$, Malech $\mathrm{HL}$ : Effect of 1,25-dihydroxyvitamin $\mathrm{D}_{3}$, lipopolysaccharide, or lipoteichoic acid on the expression of NADPH oxidase components in cultured human monocytes. J Immunol. 1991, 147:3066-3071.

179. Bao BY, Ting HJ, Hsu JW, Lee YF: Protective role of 1a, 25dihydroxyvitamin $D_{3}$ against oxidative stress in nonmalignant human prostate epithelial cells. Int J Cancer. 2008, 122:2699-2706.

180. Somjen D, Katzburg S, Grafi-Cohen M, Knoll E, Sharon O, Posner GH: Vitamin D metabolites and analogs induce lipoxygenase mRNA expression and activity as well as reactive oxygen species (ROS) production in human bone cell line. J Steroid Biochem Mol Biol. 2011, 123:85-89.

181. Garcion E, Sindji L, Leblondel G, Brachet P, Darcy F: 1,25-dihydroxyvitamin $D_{3}$ regulates the synthesis of $\gamma$-glutamyl transpeptidase and glutathione levels in rat primary astrocytes. J Neurochem. 1999, 73:859-866.

182. Martins MA, Catta-Preta M, Mandarim-de-Lacerda CA, Aguila MB, Brunini TC, Mendes-Ribeiro AC: High fat diets modulate nitric oxide biosynthesis and antioxidant defence in red blood cells from C57BL/6 mice. Arch Biochem Biophys. 2010, 499:56-61.

183. Jebelovszki E, Kiraly C, Erdei N, Feher A, Pasztor ET, et al: High-fat dietinduced obesity leads to increased NO sensitivity of rat coronary arterioles: role of soluble guanylate cyclase activation. Am J Physiol Heart Circ Physiol. 2008, 294:H2558-H2564.

184. Vignini A, Nanetti L, Moroni C, Testa R, Sirolla C, et al: Platelet nitric oxide production and IR: relation with obesity and hypertriglyceridemia. Nutr Metab Cardiovasc Dis. 2008, 18:553-558.
185. Tsuchiya K, Sakai H, Suzuki N, Iwashima F, Yoshimoto T, et al: Chronic blockade of nitric oxide synthesis reduces adiposity and improves insulin resistance in high fat-induced obese mice. Endocrinology. 2007, 148:4548-4556.

186. Cook S, Hugli O, Egli M, Menard B, Thalmann S, et al: Partial gene deletion of endothelial nitric oxide synthase predisposes to exaggerated high-fat diet-induced insulin resistance and arterial hypertension. Diabetes. 2004, 53:2067-2072

187. Perreault M, Marette A: Targeted disruption of inducible nitric oxide synthase protects against obesity-linked insulin resistance in muscle. Nat Med. 2001, 7:1138-1143.

188. Chang JM, Kuo MC, Kuo HT, Hwang SJ, Tsai JC, et al: 1-a,25Dihydroxyvitamin $D_{3}$ regulates inducible nitric oxide synthase messenger RNA expression and nitric oxide release in macrophage-like RAW264.7 cells. J Lab Clin Med. 2004, 143:14-22.

189. Garcion E, Nataf S, Berod A, Darcy F, Brachet P: 1,25-Dihydroxyvitamin $D_{3}$ inhibits the expression of inducible nitric oxide synthase in rat central nervous system during experimental allergic encephalomyelitis. Brain Res Mol Brain Res. 1997, 45:255-267.

190. Equils O, Naiki Y, Shapiro AM, Michelsen K, Lu D, et al: 1,25Dihydroxyvitamin $D_{3}$ inhibits lipopolysaccharide-induced immune activation in human endothelial cells. Clin Exp Immunol. 2006, 143:58-64.

191. Zittermann A, Frisch S, Berthold HK, Götting C, Kuhn J, et al: Vitamin D supplementation enhances the beneficial effects of weight loss on cardiovascular disease risk markers. Am J Clin Nutr. 2009, 89:1321-1327.

192. Sneve M, Figenschau Y, Jorde R: Supplementation with cholecalciferol does not result in weight reduction in overweight and obese subjects. Eur J Endocrinol. 2008, 159:675-684.

193. Boon N, Hul GB, Sicard A, Kole E, Van Den Berg ER, et al: The effects of increasing serum calcitriol on energy and fat metabolism and gene expression. Obesity (Silver Spring). 2006, 14:1739-1746.

194. Jorde R, Sneve M, Torjesen P, Figenschau Y: No improvement in cardiovascular risk factors in overweight and obese subjects after supplementation with vitamin $D_{3}$ for 1 year. J Intern Med. 2010, 267:462-472.

195. Lumb GA, Mawer EB, Stanbury SW: The apparent vitamin D resistance of chronic renal failure: a study of the physiology of vitamin $D$ in man. Am J Med. 1971, 50:421-444.

196. Mawer EB, Backhouse J, Holman CA, Lumb GA, Stanbury SW: The distribution and storage of vitamin $D$ and its metabolites in human tissues. Clin Sci. 1972, 43:413-431.

197. Jorde R, Sneve M, Torjesen PA, Figenschau Y, Gøransson LG, Omdal R: No effect of supplementation with cholecalciferol on cytokines and markers of inflammation in overweight and obese subjects. Cytokine. 2010, 50:175-180.

198. Sun $X$, Zemel MB: Calcium and 1,25-dihydroxyvitamin $D_{3}$ regulation of adipokine expression. Obesity (Silver Spring). 2007, 15:340-348.

199. Gao D, Trayhurn P, Bing C: 1,25-Dihydroxyvitamin $D_{3}$ inhibits the cytokine-induced secretion of MCP-1 and reduces monocyte recruitment by human preadipocytes. Int J Obes (Lond) 2013, 37(3):357-65.

200. Marcotorchino J, Gouranton E, Romier B, Tourniaire F, Astier J, et al: Vitamin $D$ reduces the inflammatory response and restores glucose uptake in adipocytes. Mol Nutr Food Res. 2012, 56:1771-1782.

201. McCarthy MF, Thomas CA: PTH excess may promote weight gain by impeding catecholamine-induced lipolysis-implications for the impact of calcium, vitamin D, and alcohol on body weight. Medical Hypotheses. 2003, 61:535-542.

202. Bell NH, Shaw S, Turner RT: Evidence that calcium modulates circulating 25-hydroxyvitamin D in man. J Bone Miner Res. 1987, 2:211-214.

203. Luong KV, Nguyen LT: Coexisting hyperthyroidism and primary hyperparathyroidism with vitamin D-deficient osteomalacia in a Vietnamese immigrant. Endocr Pract. 1996, 2:250-254.

\section{doi:10.1186/1475-2891-12-89}

Cite this article as: vinh quốc Lương and Nguyễn: The beneficial role of vitamin $D$ in obesity: possible genetic and cell signaling mechanisms. Nutrition Journal 2013 12:89. 